\title{
Tree Planting Configuration Influences Shade on Residential Structures in Four U.S. Cities
}

\author{
Won Hoi Hwang, P. Eric Wiseman, and Valerie A. Thomas
}

\begin{abstract}
Expanding urbanization, characterized by increased impervious surfaces and decreased tree canopy, is contributing to rising urban temperatures. This trend has implications for energy consumption and human health, which urban trees may help mitigate by casting shade upon building surfaces. This study looks at how tree form and placement can improve on current shade tree planting guidelines to more effectively use shade trees to offset this trend. Shade provision is not only a function of tree characteristics but also daily, seasonal, and latitudinal variability in sunlight exposure. In order to understand how these variables influence shade provision and to evaluate existing tree planting guidelines, a computer program called Shadow Pattern Simulator was employed to quantify shade cast by a single tree upon a prototypical residential structure in four U.S. cities. A total of 576 shade simulations showed large trees situated within five meters on the east or west aspect of the structure provided the greatest amount of shade during the cooling season. The simulation results affirm existing tree planting guidelines in the northern latitude that recommend planting shade trees on the east or west aspect while avoiding tree plantings on the south to minimize the heating penalty of unwanted shade in northern latitudes. However, planting trees on southerly aspect should not be discounted in southern latitudes because the shorter heating season lessens the detrimental heating penalty of unwanted shade while providing much-needed cooling season shade.

Key Words. Climate Change; Cooling; Energy Conservation; Heat Stress; Heating; Urban Heat Island; Urban Tree Canopy.
\end{abstract}

Trees situated in urban environments can significantly influence ambient air temperatures through evapotranspiration and shading (Akbari 2002). Urbanization displaces tree canopy cover with buildings and pavement, which absorb, retain, and reradiate heat at greater rates than vegetation. As a result, urban areas tend to have higher air temperatures than outlying rural areas where vegetation is more abundant-this phenomenon is known as the urban heat island (UHI) effect. The trend of increasing impervious surfaces and decreasing tree canopy cover in major U.S. cities (Nowak and Greenfield 2012) has been implicated as a key driver of rising urban temperatures nationwide. Stone (2007) reported that, from 1951 to 2000, the temperature of 50 large U.S. cities increased at a higher average rate per decade than comparable rural areas. Given current trends in land use and demographics, the UHI effect will likely impact an ever-expanding land area and population base in the future, which could have significant implications for human health and building energy consumed to cool buildings.
In urban areas, the UHI effect increases the incidence of extreme heat events (EHEs)-oppressive conditions due to a combination of hot and humid weather-leading to heat-related morbidity and mortality of people (Luber and McGeehin 2008). Exacerbating EHEs in urban areas is the lack of shade trees and other vegetation, increasing exposure of urban residents to more heat stress compared to their rural counterparts (Patz et al. 2007). Even in the absence of EHEs, urbanites must still endure the physical discomfort and stress of the UHI effect during hot summer months. The human thermal comfort index (HTCI) is an indicator used to identify the level at which increased temperatures cause heat-related illness. Research has shown that neighborhoods with sparse vegetation have higher temperatures and HTCIs (Harlan et al. 2006). Heatrelated health disorders not only diminish the quality of life for urbanites, but also have significant economic impacts. From 2002 to 2009, health care costs for heat-related diseases in the U.S. were about USD \$5.3 billion (Knowlton et al. 2011). 
The UHI effects also impact energy consumption for cooling buildings. During EHEs, increased use of air conditioning puts a strain on electric utility grids, often leading to infrastructure failures and brownouts (Kurita and Sakurai 1988; Walsh 2013). Each $1^{\circ} \mathrm{C}$ rise in urban temperature typically increases electricity demand by $2 \%$ to $4 \%$ (Akbari et al. 2001). And because electricity generation relies heavily on extraction and combustion of fossil fuels in many parts of the U.S., increased energy demand for cooling also impacts air and water quality. Electricity generation emits an average of $0.45 \mathrm{~kg}$ of carbon dioxide and requires 157 liters of water for each kWh generated (U.S. Government Accountability Office 2012; Wilson et al. 2012). With the average U.S. residence consuming about $900 \mathrm{kWh}$ (about $6 \%$ of which is air conditioning) per month in 2012 (U.S. Energy Information Administration 2014), the annual carbon and water footprint of electricity consumption per U.S. residence is nearly $400 \mathrm{~kg}$ and 142,000 L, respectively. Moreover, costs of electricity for air conditioning may create financial hardships for both businesses and residences, particularly in economically disadvantaged urban neighborhoods (Harlan et al. 2007). Compounding the UHI effect on cooling energy consumption is climate change. Given predictions of a warmer planet in the future (U.S. Global Change Research Program 2009), demand for cooling energy will likely increase in some regions of the U.S.

Numerous strategies have been proposed to counteract the UHI effect and thereby mitigate its impacts on human health and energy consumption. Increasing tree canopy cover through the strategic planting of trees in the built environments is increasingly seen as a key strategy for mitigating the UHI effect. Because areas with shade trees are typically cooler, occupants of shaded buildings tend to consume less energy for air conditioning during the summer months. According to the Arbor Day Foundation, its Energy-Saving Trees program has distributed more than 140,000 trees in six U.S. cities, and these trees are expected to save up to 264 million kWh of energy by 2025 (U.S. Administration 2014). Planting more trees for energy conservation is clearly important, yet residential parcels are increasingly constrained for space and resources for planting shade trees. Average yard sizes in the U.S. are decreasing due to an increase in home sizes and a decrease in lot sizes (Sarkar 2011), which limits spaces for planting multiple shade trees. Moreover, community tree distribution programs are often limited to providing one tree per parcel in order to distribute trees equitably. Therefore, to maximize the health and energy benefits of trees, it is crucial for researchers to understand how the selection and placement of a single tree on a residential parcel influences shading (and therefore energy consumption) for nearby buildings.

Shade provision by a single tree onto a building is a function of two factors: tree form and tree placement. Tree form describes the physical attributes of a tree, whereas tree placement describes its location relative to a building targeted for shading. Each of these two factors comprises a suite of variables (Figure 1) that-in combination-constitute a unique tree planting configuration, hereafter referred to as TPC (see METHODOLOGY for a full description of how TPCs are configured). The interaction between a particular TPC and the diurnal and seasonal patterns of sunlight in a particular geographic location dictate the subsequent shade cast upon a building. Of all the variables that constitute a TPC, Rudie and Dewers (1984) found that tree height and distance from a building were significant variables in shade provision. Numerous other studies have shown that the cardinal direction of a tree from a building is also important: large, dense-canopied trees positioned on the west aspect of a building are commonly reported to provide the greatest cooling benefits (Hildebrandt and Sarkovich 1998; Simpson 2002; Donovan and Butry 2009; Ko and Radke 2014). A study conducted in Sacramento, California, U.S. found that trees on the west aspect of buildings saved the most cooling energy - as much as 400 $\mathrm{kWh}$ annually-followed by trees on the east and south aspects (Simpson 2002). Similarly, Nikoofard et al. (2011) found that a structure with a tree on the west aspect consumed the least annual cooling energy (as much as $554 \mathrm{kWh}$ less) in four Canadian cities, followed by trees on the east and south aspects.

Because tree form and placement are crucial factors in shade provision, authoritative sources throughout the U.S. have published regional guidelines on tree planting for energy conservation (Table 1). These guidelines tend to affirm the general recommendation of placing a large tree in close proximity to the west aspect of a building. How- 
ever, it is unclear whether these recommendations take into account the interaction of the physical form and placement of a shade tree with the diurnal and seasonal patterns of sun exposure in a given geographic location, all of which influence shade coverage and duration. The study reported here was undertaken to quantify, using computer simulations, the shade cast by a single tree onto a prototypical residential structure in four U.S. cities situated across a broad latitudinal gradient. The goal of the study was to characterize daily and

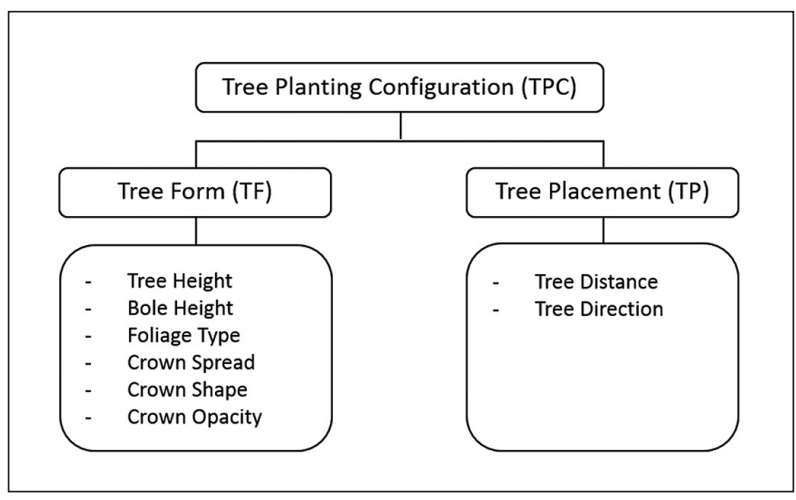

Figure 1. Integral factors and component variables in a tree planting configuration (TPC) that influence shade provision. These factors and variables were used in computer simulations of shade provision by a single tree onto a prototypical residential structure in four U.S. cities. seasonal patterns of tree shade in order to ascertain whether regional tree planting guidelines provide appropriate recommendations for maximizing tree shade given the local solar conditions.

\section{METHODOLOGY}

\section{Study Areas}

Four U.S. cities were chosen for tree shade simulations: Minneapolis, Minnesota; Indianapolis, Indiana; Charlotte, North Carolina; and Orlando, Florida (Figure 2). Their locations span a broad latitudinal gradient of the conterminous U.S. and represent diverse climate zones based on a 30-year average of annual cooling and heating degreedays (Baechler et al. 2010) (Table 2). These cities have also been used as reference cities for i-Tree Streets (an urban forest assessment software), which models a range of tree benefits, including energy conservation (McPherson 2010). In order to better understand the implications of annual patterns of shade provision for these four cities, cooling and heating seasons were defined based on the climate data obtained from the National Oceanic and Atmospheric Administration (2011). During the cooling season (Table 2,

Table 1. Regional tree planting guidelines for energy conservation published by authoritative sources.

\begin{tabular}{|c|c|c|c|}
\hline Area & $\begin{array}{l}\text { Tree placement } \\
\text { direction (distance) }\end{array}$ & Tree form & Source(s) \\
\hline General & $\begin{array}{l}\mathrm{W} \\
\mathrm{S}\end{array}$ & $\begin{array}{l}\text { Trees with crown lower to } \\
\text { the ground; Deciduous trees } \\
\text { with high, spreading crowns }\end{array}$ & U.S. Department of Energy \\
\hline Minnesota & $\mathrm{W}, \mathrm{E}(6 \mathrm{~m})$ & $\begin{array}{l}\text { At least three meters higher } \\
\text { than window with large canopy }\end{array}$ & University of Minnesota Extension \\
\hline North Carolina & W, E, S (3-9 m) & Not specified & $\begin{array}{l}\text { North Carolina Cooperative Extension Service; } \\
\text { TreesCharlotte }\end{array}$ \\
\hline Florida & W, E, S, SE & $\begin{array}{l}\text { deciduous trees on the } \\
\mathrm{S} \text { and } \mathrm{SE}\end{array}$ & $\begin{array}{l}\text { Florida Solar Energy Center; University of } \\
\text { Florida IFAS Extension }\end{array}$ \\
\hline $\begin{array}{l}\text { Midwest } \\
\text { (Minneapolis) }\end{array}$ & $\begin{array}{l}\mathrm{W}, \mathrm{E}(9-15 \mathrm{~m} ; \mathrm{min} .3 \mathrm{~m}) \\
\mathrm{S}(3-6 \mathrm{~m})\end{array}$ & $\begin{array}{l}\text { Not specified } \\
\text { Solar-friendly trees }\end{array}$ & $\begin{array}{l}\text { Center for Urban Forest Research, USDA Forest } \\
\text { Service }\end{array}$ \\
\hline $\begin{array}{l}\text { Lower Midwest } \\
\text { (Indianapolis) }\end{array}$ & $\begin{array}{l}\mathrm{W}, \mathrm{E}(9-15 \mathrm{~m} ; \mathrm{min} .3 \mathrm{~m}) \\
\mathrm{S}(3-6 \mathrm{~m})\end{array}$ & $\begin{array}{l}\text { Not specified } \\
\text { Solar-friendly trees }\end{array}$ & $\begin{array}{l}\text { Center for Urban Forest Research, USDA Forest } \\
\text { Service }\end{array}$ \\
\hline $\begin{array}{l}\text { Piedmont } \\
\text { (Charlotte) }\end{array}$ & $\begin{array}{l}\mathrm{W}, \mathrm{E}(9-15 \mathrm{~m} ; \mathrm{min} .3 \mathrm{~m}) \\
\mathrm{S}(3-6 \mathrm{~m})\end{array}$ & $\begin{array}{l}\text { Not specified } \\
\text { Solar-friendly trees }\end{array}$ & $\begin{array}{l}\text { Center for Urban Forest Research, USDA Forest } \\
\text { Service }\end{array}$ \\
\hline $\begin{array}{l}\text { Central Florida } \\
\text { (Orlando) }\end{array}$ & $\begin{array}{l}\mathrm{W}, \mathrm{E}(9-15 \mathrm{~m} ; \mathrm{min} .3 \mathrm{~m}) \\
\mathrm{S}(3-6 \mathrm{~m})\end{array}$ & $\begin{array}{l}\text { Not specified } \\
\text { Solar-friendly trees }\end{array}$ & $\begin{array}{l}\text { Center for Urban Forest Research, USDA Forest } \\
\text { Service }\end{array}$ \\
\hline
\end{tabular}

${ }^{\mathrm{z}}$ Direction and distance from a building to be shaded.

Note: Asterisk $\left(^{\star}\right)$ indicates solar-friendly trees are deciduous trees that allow sunlight to pass through or under the crown in winter for passive solar heating of buildings (McPherson et al. 2005). 
values with asterisk), when monthly mean temperatures exceed $18.3^{\circ} \mathrm{C}$, there is increased airconditioning demand, as well as heat stress risk for people, thereby emphasizing the need for tree shade. The heating season (Table 2, values in bold), when monthly mean temperatures are less than $18.3^{\circ} \mathrm{C}$, however, defines a period when tree shade may be undesirable because it diminishes passive solar heating of buildings and thus potentially increases heating costs.

\section{Prototypical Residential Structure}

Computer simulations of shade provision were performed using a prototypical residential structure. The structure was defined as a single-level residence with a north-south orientation and south-facing

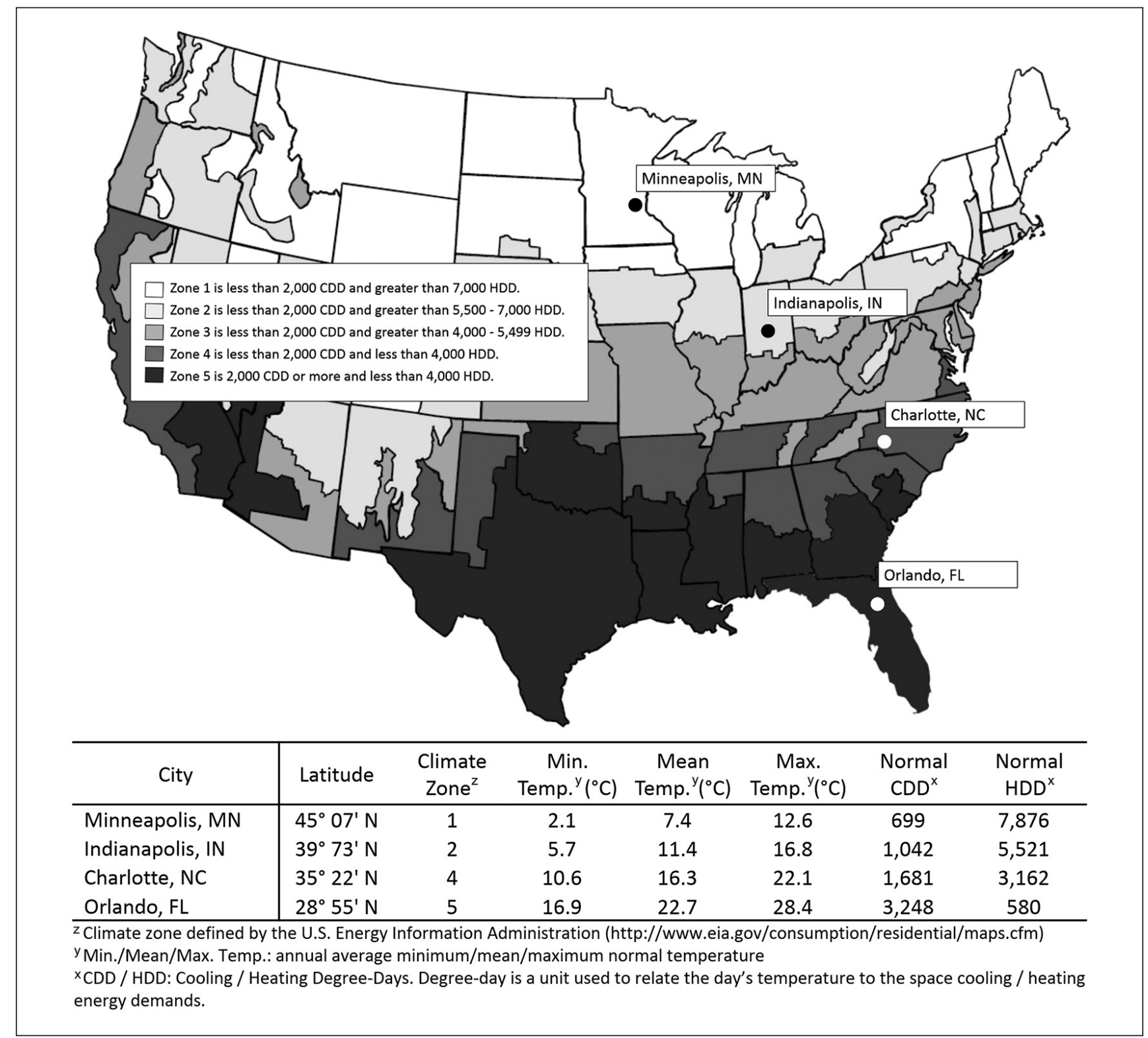

Figure 2. Location and climatic information for four U.S. cities where computer simulations of shade cast by a single tree onto a prototypical residential structure were performed. 
Table 2. Cooling and heating seasons in four U.S. cities where computer simulations of shade cast by a single tree onto a prototypical residential structure were performed. Cooling season (values in bold text) is when monthly mean temperature is above $18.3^{\circ} \mathrm{C}$, while heating season is when monthly mean temperature is below $18.3^{\circ} \mathrm{C}$. Peaks of the cooling season-values denoted with an asterisk $\left(^{*}\right)$-are when monthly mean temperatures are the highest.

\begin{tabular}{|c|c|c|c|c|c|c|c|c|c|c|c|c|}
\hline & Jan & Feb & Mar & Apr & May & Jun & Jul & Aug & Sep & Oct & Nov & Dec \\
\hline \multicolumn{13}{|c|}{$T_{\text {Mean }}{ }^{y}\left({ }^{\circ} \mathrm{C}\right)$} \\
\hline $\mathrm{MN}^{\mathrm{M}}$ & -9.1 & -6.2 & 0.4 & 8.6 & 15.1 & 20.4 & $23.2^{\star}$ & 21.8 & 16.7 & 9.4 & 0.9 & -6.8 \\
\hline $\mathrm{IN}^{\mathrm{z}}$ & -2.2 & 0.1 & 5.7 & 11.7 & 17.1 & 22.2 & $24.1^{*}$ & 23.4 & 19.4 & 12.8 & 6.4 & -0.2 \\
\hline $\mathrm{NC}^{\mathrm{z}}$ & 4.5 & 6.6 & 10.7 & 15.2 & 19.7 & 24.1 & $25.8^{*}$ & 25.2 & 21.6 & 15.7 & 10.4 & 5.8 \\
\hline $\mathrm{FL}^{\mathrm{z}}$ & 15.7 & 17.2 & 19.4 & 21.8 & 25.2 & 27.4 & 28.2 & $28.2^{\star}$ & 27.3 & 24.2 & 20.3 & 17.0 \\
\hline \multicolumn{13}{|c|}{$C D D^{y}$} \\
\hline MN & 0 & 0 & 0 & 5 & 37 & 158 & $276^{*}$ & 205 & 66 & 6 & 0 & 0 \\
\hline IN & 0 & 0 & 2 & 13 & 69 & 226 & $323^{*}$ & 288 & 128 & 16 & 1 & 0 \\
\hline $\mathrm{NC}$ & 0 & 0 & 0 & 6 & 45 & 173 & $266^{*}$ & 231 & 90 & 9 & 1 & 0 \\
\hline FL & 45 & 59 & 118 & 199 & 380 & 490 & 549 & $553^{*}$ & 483 & 331 & 147 & 70 \\
\hline \multicolumn{13}{|c|}{$H D D^{y}$} \\
\hline $\mathrm{MN}$ & 1531 & 1236 & 998 & 530 & 218 & 44 & 5 & 14 & 154 & 507 & 939 & 1404 \\
\hline IN & 990 & 783 & 558 & 248 & 65 & 4 & 0 & 0 & 29 & 206 & 495 & 879 \\
\hline $\mathrm{NC}$ & 770 & 592 & 433 & 200 & 53 & 3 & 0 & 0 & 23 & 183 & 430 & 701 \\
\hline FL & 193 & 115 & 59 & 12 & 1 & 0 & 0 & 0 & 0 & 5 & 42 & 144 \\
\hline
\end{tabular}

${ }^{z}$ U.S. study locations: Minneapolis, Minnesota (MN); Indianapolis, Indiana (IN); Charlotte, North Carolina (NC); and Orlando, Florida (FL).

${ }^{y} \mathrm{~T}_{\text {Mean }}$ : 1981-2010 monthly normal of mean temperature; CDD: Cooling Degree-Days; and HDD: Heating Degree-Days (Degree-day is a unit used to relate the day's temperature to the space cooling/heating energy demands).

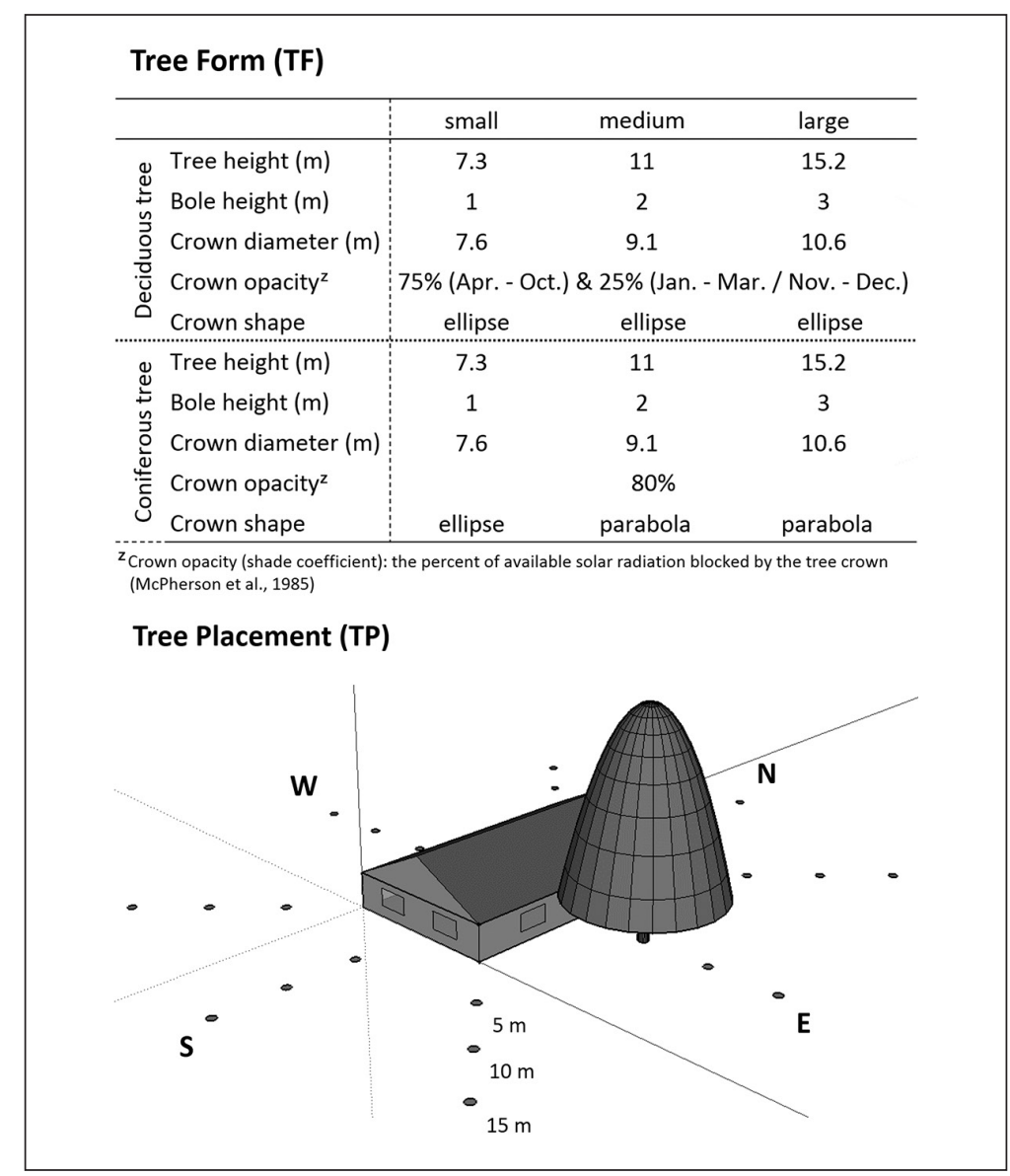

Figure 3. Tree Form (TF) and Tree Placement (TP) variables used in the computer simulation of tree shade cast upon a prototypical residential structure in four U.S. cities. A single coniferous tree or deciduous tree of specified physical dimensions was simulated at three distances on eight azimuths to generate 144 unique tree planting configurations (TPCs). gable end (Figure 3). The floor area was approximately $200 \mathrm{~m}^{2}(11 \mathrm{~m} \times 18.2 \mathrm{~m})$, and the building had a total surface area of $410.6 \mathrm{~m}^{2}$ (four walls and two roof halves). Although the average floor area of a new single-family house built since 2000 is approximately $211 \mathrm{~m}^{2}$ (Sarkar 2011; U.S. Census Bureau 2012), a $200 \mathrm{~m}^{2}$ floor area was chosen for computational convenience.

\section{Tree Planting Configurations (TPCs)}

For the tree shade simulations, 144 unique single-tree TPCs were permutated using combinations of tree form and tree placement variables (Figure 3). Tree form (TF) consisted of five variables: tree height, bole height, crown diameter, crown opacity, and crown shape. Three coniferous and three deciduous trees ranging, in height from $7.3 \mathrm{~m}$ (small) to $15.2 \mathrm{~m}$ (large), were simulated using the TF variables (Simpson and McPherson 1998; Simpson 2002). In order to avoid space conflicts between the structure and the tree's crown, tree distance from the structure was set at a minimum five meters with two additional five-meter intervals (10 and $15 \mathrm{~m}$ ). Tree distances were permutated with eight directions from the structure (four cardinal 
and four intercardinal). The simulated values for all TPC variables used in this study were based upon data from previous studies, typifying many urban landscape trees found in the U.S. (Simpson and McPherson 1998; Simpson 2002; Troxel et al. 2013).

\section{Shade Simulation Framework}

Tree shade simulations were processed with a computer program called Shadow Pattern Simulator (SPS, Windows Version 2.0), which was developed by scientists with the U.S. Forest Service (Simpson and McPherson 1998). Based on specifications for both a tree and a structure, the SPS program precisely estimated hourly shaded areas on each building surface as a percent of total exposed area [accuracy has been reported at 95\%; see McPherson et al. (1985) for more details about the SPS program]. The SPS program had several limitations: it could only simulate basic geometric crown shapes, a static crown opacity factor, and a rectangularshaped building. Nonetheless, it has tremendous computational capability for understanding daily and seasonal trends in shade provision and has been used in previous studies to quantify shaded areas on building surfaces as an intermediate step for energy consumption simulations (Simpson and McPherson 1998; Simpson 2002; Sawka et al. 2013).

\section{Tree Shade Simulations}

Each simulation using the SPS program calculated tree shade coverage on building surfaces using the following inputs: a TPC permutation, building specifications, study area, and simulation time frame. Simulations were run at diurnal half-hour intervals (beginning of hour, middle of hour, and end of hour), and then the three half-hour shade coverage estimates were averaged for each hourly estimate. Monthly simulations were run one day per month (each at the middle of the month) over a year and then quantified as daily shade surface area (hereafter referred to as shade provision), which represented the accumulated daily value of shade coverage on building surfaces from sunrise to sunset:

$$
\text { Shade Provisions }(S)=\sum \text { Ksunrise }+\ldots+\text { Ksunset }
$$

where $\mathrm{K}$ is an hourly shade estimate. Two measures of shade provision are reported here based on the simulations: average shade provision and maxi- mum shade provision. Average shade provision is the value calculated by summing shade provisions divided by the number of months during either the cooling or heating season. Maximum shade provision constitutes the greatest value (of single-day shade provision) over the duration of each season. Across the four study areas, a total of 6,912 shade provision estimates were acquired through a total of 576 tree shade simulations (144 TPC permutations $\times 4$ study areas $\times 12$ months). Average and maximum shade provision values were then evaluated in the context of annual cooling and heating degreedays data for each of the four study areas (Table 2).

\section{RESULTS AND DISCUSSION}

\section{Overall Trends in Shade Provision}

Within the calendar-year simulation time frame, maximum daily shade cast upon the exterior surface area of the prototypical residential structure ranged from $0 \mathrm{~m}^{2}$ (no shade) to $580 \mathrm{~m}^{2}$ (deciduous tree) or $706 \mathrm{~m}^{2}$ (coniferous tree), depending on the particular study area and simulated TPC. Figure 4 shows data for the large, nearby trees at the latitudinal extremes (Minneapolis and Orlando), which best exemplify the differential influence of TPC and latitude. In all simulations, compared to a deciduous tree, a coniferous tree provided more shade because of its higher crown opacity and year-round foliation. In addition, the larger the tree placed adjacent to the structure, the greater the shade provided. In contrast, smaller trees placed at distances farther from the structure provided low levels of shade. Small trees placed $\geq 10 \mathrm{~m}$ away or medium trees $\geq 15 \mathrm{~m}$ away typically produced shade coverage less than $112 \mathrm{~m}^{2}$, the 75th percentile of all shade estimates over the entire year (Figure 5). Among small and medium trees, only a few trees on the east or west aspect of the building provided shade greater than $112 \mathrm{~m}^{2}$, during the yearlong simulation time frame.

Differences in shading amongst study areas were due to latitudinal differences in sun angle above the horizons during the course of the day and year. In the same TPC permutation, trees placed on the southern aspects of the structure in northern cities cast more shade than those in southern cities (Figure 4). Because the sun was relatively lower above the horizon throughout the day and year in northern cities, the tree crowns intercepted more sunlight. Shade pro- 
vision by the south-positioned tree decreased when moving from northern to southern cities because of the higher sun angles in southern cities; in particular, shade decreased substantially in May through July when sun angles were highest. Conversely, shade provision by a tree on the north increased when moving to southern cities. However, trees on northern aspects produced very limited overall shade because of the short intervals that they cast shade each day during the summer (at certain times of the year they never cast shade due to seasonal changes in sunrise and sunset). As well, when moving from northern to southern cities, shade provision from trees on east or west aspects increased in winter months due to lower sun angles, while it decreased in summer months because sunlight passed over the tree crown. The latitudinal differences in shade from east to west aspect trees, among the various locations, were subtle because sun

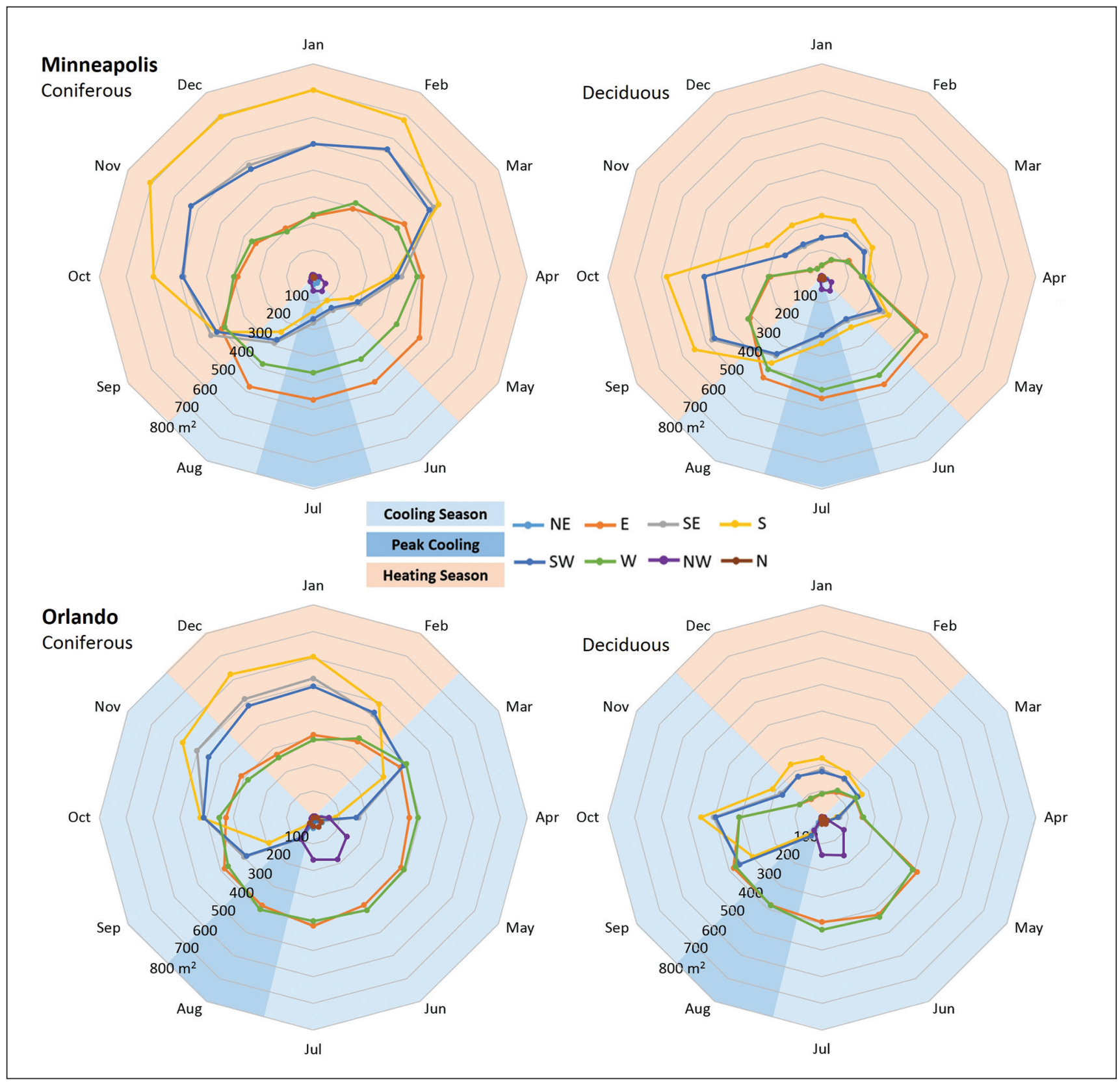

Figure 4. Annual patterns of maximum shade provision produced by a large coniferous tree and a large deciduous tree placed five meters away from a prototypical residential structure in Minneapolis, MN (top) and Orlando, FL (bottom). Each node represents the building surface area $\left(\mathrm{m}^{2}\right)$ shaded over the course of a single day during the middle of each month. (Note: Due to the scale of the graphs, shade provisions by northerly placed trees may be imperceptible at the center of the graphs.) 


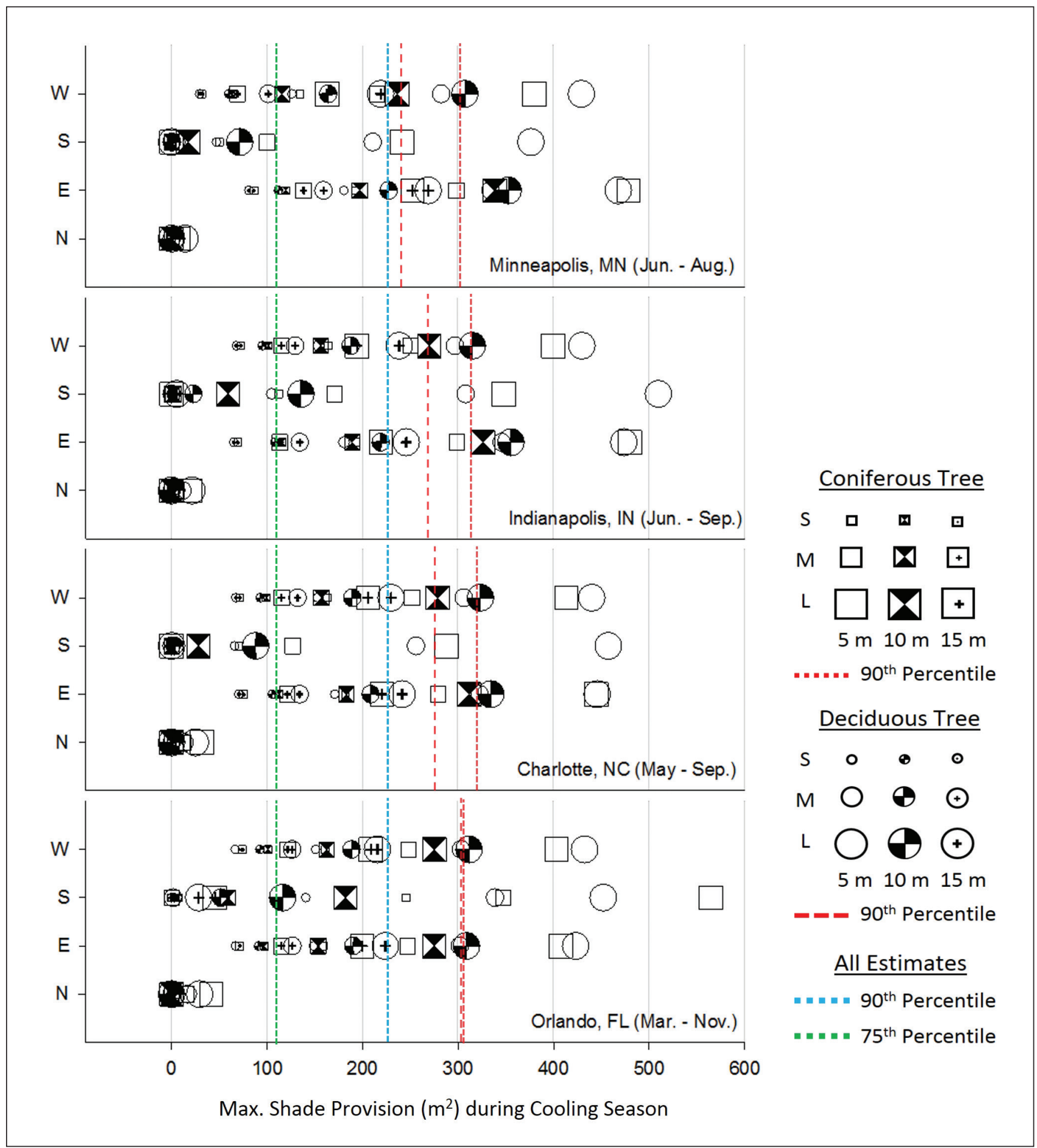

Figure 5. Maximum shade provisions produced by large coniferous trees (squares) and deciduous trees (circles) during the cooling seasons in four U.S. cities (the duration is listed next to the city name in each graph). Each data point depicts the maximum building surface area $\left(\mathrm{m}^{2}\right)$ shaded over by different tree sizes (S: small, M: medium, and L: large) the course of a single day during the entire cooling season. Red lines denote the 90th percentile of maximum shade provision for coniferous or deciduous tree planting configurations in a specific city. Blue and green lines denote the 90 th percentile $\left(222 \mathrm{~m}^{2}\right)$ and the 75 th percentile $\left(112 \mathrm{~m}^{2}\right)$ of maximum shade provision for all tree planting configurations across four U.S. cities. 
angles in the early morning and the late afternoon are less influenced by latitude. Because smaller trees and treesplaced on thenorth aspects of a structureprovided negligible levels of shade, discussion in the following sections primarily focuses on the latitudinal nuances of large trees placed on east, south, and west aspects.

\section{Shade Provision in the Cooling Season}

Across study sites, the cooling season ranges from three months (Minneapolis) to nine months (Orlando) (Table 2). During these stretches of time, maximizing tree shade on building surfaces is critical for energy conservation and human health. A more practical measure of sustained shade benefit is the average shade provision, which is the value calculated by summing shade provision (coverage) divided by the number of months over the duration of the cooling season. The shade simulations revealed some notable trends in tree shade (only data for large, nearby trees is shown in Table 3 to best exemplify the influence of aspect and latitude on shade). First, when considering tree types, coniferous trees provided greater average shade provision (averaged values over the duration of the cooling season) than the deciduous trees-these differences were most pronounced in Orlando where the cooling season is considerably longer, whereby dense, persistent foliage is more advantageous. Second, tree placement on the east or west aspect of the structure provided greater average tree shade over the course of the season, regardless of latitude. In contrast, shade was consistently lowest for trees on the south or southwest aspect because the sun angle is very high and therefore sunlight passes over the top of the tree during the cooling season. All of these trends in shade provision also held for the peak of the cooling season in July or August. Average daily shade provision by either tree types during the cooling season (and its peak) diminished when moving from northern to southern cities due to progressively higher sun angles as moving toward more southerly locations.

The measure of maximum shade provision (single-day coverage value) gives an indication of how tree shade could be maximized on a single day. During the cooling season, the maximum daily shade provision of all TPC permutations on building surfaces ranged from $445 \mathrm{~m}^{2}$ (in Charlotte) to $564 \mathrm{~m}^{2}$ (in Orlando) (Figure 5). Large, nearby trees consistently provided the most shade, with the majority of these TPCs exceeding the 90th percentile of all TPC permutations. In three of the four localities, tree placement on the south aspect maximized daily shade in the cooling season. Minneapolis was the exception, where shade was maximized by an east-positioned tree. Due to the longer cooling season in southern localities, extending well into autumn when the sun angle is low, south-positioned trees maximized sunlight interception. Across all localities, although coniferous trees provided greater average shade provision, deciduous trees tended to provide the maximum shade (of any single-day values) (Figure 5). The differences in shade provision between coniferous and deciduous trees were primarily due to the elliptical crown shape simulated for deciduous trees, which have their widest diameter positioned at a greater vertical height above the ground than do parabolic coniferous trees. In general, differences in shade provision between tree types diminished when moving from northern to southern localities as the duration of the cooling season increased.

\section{Shade Provision During Peak Cooling Demand}

Historical weather data shows that both average monthly temperatures and cooling degree-days (CDDs) peak in the month of July or August, depending on the study area (Table 2). The most severe EHEs in the U.S. since 1980 have typically occurred during July in locations such as Chicago, Illinois (1980, 1983, 1986, and 1995); Kansas City, Missouri (1980); Memphis, Tennessee (1980); Philadelphia, Pennsylvania (1993); and Phoenix, Arizona (2005) (Whitman et al. 1997; U.S. Environmental Protection Agency 2006; Centers for Disease Control and Prevention 2013). The simulation results showed that during the peak of the cooling season both coniferous and deciduous trees placed on the east aspect of the structure cast the most shade on building surfaces, followed by trees placed on the west. Orlando was a notable exception, with trees on the west aspects providing more shade (Table 3 ). Compared to trees on other aspects, south-positioned trees provided lower levels of shade across all study areas due to the high sun angles that occur at midday during peak cooling demand. However, differences in shade provision between trees on the south and on other aspects decreased when moving to- 
Table 3. Average shade provision cast by a large coniferous and a large deciduous tree placed five meters from a prototypical residential structure in four U.S. cities during the cooling season, peak of the cooling season, and the heating season. Only east to west aspects are shown. Each value is the average of daily cumulative shade coverage over the duration of the season. Minimum and maximum shade provision values for each season are denoted with bold text.

\begin{tabular}{|c|c|c|c|c|c|c|}
\hline & \multicolumn{3}{|c|}{ Deciduous tree shade $\left(\mathrm{m}^{2}\right)$} & \multicolumn{3}{|c|}{ Coniferous tree shade $\left(\mathrm{m}^{2}\right)$} \\
\hline & $\begin{array}{l}\text { Cooling } \\
\text { season }\end{array}$ & $\begin{array}{l}\text { Peak } \\
\text { cooling }\end{array}$ & $\begin{array}{l}\text { Heating } \\
\text { season }\end{array}$ & $\begin{array}{l}\text { Cooling } \\
\text { season }\end{array}$ & $\begin{array}{l}\text { Peak } \\
\text { cooling }\end{array}$ & $\begin{array}{l}\text { Heating } \\
\text { season }\end{array}$ \\
\hline \multicolumn{7}{|c|}{ Minneapolis, MN } \\
\hline $\mathrm{E}$ & 455.1 & 458.3 & 156.5 & 466.8 & 463.9 & 324.5 \\
\hline SE & 252.4 & 221.7 & 237.3 & 202.9 & 174.9 & 449.3 \\
\hline$S$ & 282.7 & 251.6 & 304.4 & 158.3 & 130.3 & 533.1 \\
\hline SW & 246.4 & 219.4 & 235.2 & 190.2 & 159.1 & 440.1 \\
\hline $\mathrm{W}$ & 419.4 & 426.6 & 154.5 & 367.3 & 363.0 & 311.7 \\
\hline \multicolumn{7}{|c|}{ Indianapolis, IN } \\
\hline $\mathrm{E}$ & 415.4 & 431.9 & 145.6 & 422.7 & 414.8 & 312.1 \\
\hline SE & 246.8 & 149.0 & 202.6 & 205.2 & 111.8 & 424.6 \\
\hline$S$ & 277.6 & 168.8 & 259.2 & 156.8 & 65.2 & 499.7 \\
\hline SW & 244.6 & 144.6 & 202.0 & 197.6 & 105.4 & 420.6 \\
\hline $\mathrm{W}$ & 403.0 & 423.4 & 148.9 & 384.6 & 372.7 & 317.7 \\
\hline \multicolumn{7}{|c|}{ Charlotte, NC } \\
\hline $\mathrm{E}$ & 417.0 & 445.8 & 119.3 & 418.6 & 444.8 & 316.2 \\
\hline SE & 187.0 & 98.1 & 205.8 & 148.2 & 60.2 & 456.6 \\
\hline $\mathrm{S}$ & 195.9 & 91.6 & 255.1 & 95.2 & 21.7 & 514.0 \\
\hline SW & 188.5 & 93.7 & 199.7 & 143.4 & 57.0 & 439.9 \\
\hline $\mathrm{W}$ & 411.0 & 434.1 & 121.3 & 403.8 & 406.9 & 317.0 \\
\hline \multicolumn{7}{|c|}{ Orlando, FL } \\
\hline E & 298.9 & 381.0 & 91.7 & 367.9 & 383.2 & 304.7 \\
\hline SE & 143.6 & 85.4 & 173.5 & 214.8 & 89.6 & 495.1 \\
\hline $\mathrm{S}$ & 144.7 & 65.3 & 215.3 & 180.4 & 27.8 & 573.0 \\
\hline SW & 140.7 & 80.7 & 172.9 & 205.4 & 88.0 & 477.6 \\
\hline $\mathrm{W}$ & 301.0 & 382.1 & 96.2 & 375.7 & 399.3 & 298.7 \\
\hline
\end{tabular}

Note: U.S. study locations: Minneapolis, Minnesota (MN); Indianapolis, Indiana (IN); Charlotte, North Carolina (NC); and Orlando, Florida (FL).

ward northern latitudes. Using this understanding of the benefits of tree shade, it is asserted that during the peak cooling season, shade cast by a strategically placed tree could decrease temperatures of both building surfaces and interior surfaces, subsequently helping to reduce heat-related health incidents and deaths that are prevalent during EHEs.

\section{Shade Provision in the Heating Season}

Past studies have shown that tree canopy blocking sunlight during the heating season can adversely diminish the passive solar heating of structures, resulting in a heating penalty in terms of year-round energy consumption for climate control (Simpson and McPherson 1996; Simpson 1998; Simpson and McPherson 1998). In tree shade simulations during the heating season, a large tree placed on the south aspect of the structure produced a large amount of shade. Due to crown opacity and year-round foliation, coniferous trees on the south aspect cast twice as much shade as deciduous trees, depending on the study area (Table 3; Figure 4). These high shade levels became most pronounced in early autumn, usually in September, at the same time that heating energy demands typically start increasing. These conditions persisted in all localities except Orlando, where the heating season does not begin until mid-November, by which time, the sun angle has substantially dropped so that sunlight passes both under and through the crown of deciduous trees that have recently shed their leaves. Therefore, the impact of shade cast by a south-positioned deciduous tree on heating energy demand would be less significant in southern cities such as Orlando.

\section{Regional Tree Planting Guidelines}

Aimed at energy conservation, authoritative sources throughout the U.S. have published regional guidelines for shade tree planting (Table 1). While Community Tree Guides, published by the U.S. Forest Service, covers multiple states in specific climate zones (McPherson et al. 2005; McPherson et al. 2006; Peper et al. 2009; Peper et 
al. 2010), regional guidelines published by university extension programs focus solely on the associated state. Therefore, university extension guidelines tend to be more specific. For example, the Minnesota guidelines recommend a specific tree direction (either east or west), distance ( $6 \mathrm{~m}$ away), as well as tree form (large canopied tree at least $3 \mathrm{~m}$ higher than window), with which simulations of the current study agree. Even though all guidelines affirm that trees on the west aspect are the best option for shade tree planting, they often do not fully address the interaction between tree form, tree placement, and geographic latitude.

The simulations show that regional tree planting guidelines recommending planting a shade tree on the east or west aspect of a dwelling for energy conservation are appropriate. Trees on these aspects have been found to provide abundant shade during the cooling season while simultaneously minimizing unwanted shade during the heating season. In contrast, shade trees placed on the southern aspects are shown to do the opposite. Southerly-placed trees cast a lot of undesirable shade in the heating season, yet provide minimal shade during the cooling season. Therefore, planting guidelines are correct in restricting or attaching conditions for planting a tree on the south aspect. For example, a common recommendation to minimize the heating penalty of tree shade (especially in northern latitudes) is to plant a "solar-friendly tree" $-\mathrm{a}$ deciduous, high-crowned tree, which allows sunlight to pass under the tree and reach the structure during the heating season (McPherson et al. 2005; McPherson et al. 2006; Peper et al. 2009; Peper et al. 2010).

While planting guidelines tend to correctly recommended cardinal tree orientation around a dwelling, they often do not stress the important interaction between tree form and tree distance, which were found through simulations to have significant impacts that should be addressed for optimal tree planting strategies. For example, the Community Tree Guides (Table 1) recommend planting a tree at a distance between 9 and $15 \mathrm{~m}$ in order to provide effective shade on windows and walls as well as to avoid tree conflicts to the structure (McPherson et al. 2005; McPherson et al. 2006; Peper et al. 2009; Peper et al. 2010). Avoiding conflicts between a tree and a structure is an important aspect of a sustainable landscape; however, the simulation results indicated that shade provision on building surfaces noticeably decreased when placed more than five meters away from the structure. The simulations also showed that at all latitudes shade provision was reduced even more drastically with distance as the tree size decreased. This effect was evident particularly in northern latitudes when considering the average shade provision during the cooling season (Table 4). For example, in Minneapolis, with a large deciduous tree ( $15.2 \mathrm{~m}$ tall) situated at five meters on the west aspect, average shade provision was valued at $419 \mathrm{~m}^{2}$, but reduced to $303 \mathrm{~m}^{2}$ at $10 \mathrm{~m}$, and $210 \mathrm{~m}^{2}$ at $15 \mathrm{~m}$. Likewise, a small deciduous tree $(7.3 \mathrm{~m}$ tall $)$ placed at five meters on the west provided average shade provision of $114 \mathrm{~m}^{2}$, but reduced $46 \mathrm{~m}^{2}$ at $10 \mathrm{~m}$, and $18 \mathrm{~m}^{2}$ at $15 \mathrm{~m}$.

Shade simulations showed recommendations for distance associated with tree sizes. Large trees $(15.2 \mathrm{~m}$ tall) were less influenced by an increase in distance from the structure than medium $(11 \mathrm{~m}$ tall) and small $(7.3 \mathrm{~m}$ tall) trees. Large trees were shown to provide increased tree shade (exceeding the 75th percentile of all estimates over the entire year) at distances from 5 to $15 \mathrm{~m}$. On the other hand, it is recommended to plant a medium tree within $10 \mathrm{~m}$ or a small tree within $5 \mathrm{~m}$ away in order to acquire tree shade greater than $112 \mathrm{~m}^{2}$ (the 75th percentile) during the cooling season. In comparison to trees on either east or west aspects, due to higher sun angles, south-positioned trees are more sensitive to an increase in distance from the structure; regardless of tree size these trees should be placed close to the structure for tree shade to ensure adequate shade during peak cooling season while also minimizing the winter season heating penalty.

Across the study areas, the simulations support planting a shade tree on either the east or west aspect as the best option for energy conservation. However, when planting on the east or west aspect is not an option, the recommendation for shade tree selection and placement will depend on the latitude and climate. In northern latitudes (Minneapolis and Indianapolis) with longer heating seasons, trees on the southeast or southwest aspect would be the second-best option. Trees on these aspects provide constant tree shade throughout the year, casting more shade in the cooling season and less in the heating season than a southpositioned tree. In these northern latitudes, the 
Table 4. Average shade provision produced by different sizes of a coniferous and a deciduous tree placed on the west aspect of a prototypical residential structure in four U.S. cities during the cooling season, the peak of the cooling season, and the heating season. Minimum and maximum shade provision values for each season are denoted with bold text.

\begin{tabular}{|c|c|c|c|c|c|c|c|}
\hline \multirow[t]{2}{*}{ Size } & \multirow[t]{2}{*}{ Distance } & \multicolumn{3}{|c|}{ Deciduous tree shade $\left(\mathrm{m}^{2}\right)$} & \multicolumn{3}{|c|}{ Coniferous tree shade $\left(\mathrm{m}^{2}\right)$} \\
\hline & & $\begin{array}{l}\text { Cooling } \\
\text { season }\end{array}$ & $\begin{array}{l}\text { Peak } \\
\text { cooling }\end{array}$ & $\begin{array}{l}\text { Heating } \\
\text { season }\end{array}$ & $\begin{array}{l}\text { Cooling } \\
\text { season }\end{array}$ & $\begin{array}{l}\text { Peak } \\
\text { cooling }\end{array}$ & $\begin{array}{l}\text { Heating } \\
\text { season }\end{array}$ \\
\hline \multicolumn{8}{|c|}{ Minneapolis, MN } \\
\hline \multirow[t]{3}{*}{$\mathrm{L}$} & 5 & 419 & 427 & 154 & 367 & 363 & 312 \\
\hline & 10 & 303 & 305 & 99 & 225 & 220 & 163 \\
\hline & 15 & 210 & 207 & 67 & 146 & 138 & 101 \\
\hline \multirow[t]{3}{*}{ M } & 5 & 281 & 280 & 133 & 202 & 198 & 209 \\
\hline & 10 & 156 & 153 & 75 & 103 & 97 & 106 \\
\hline & 15 & 82 & 74 & 46 & 53 & 45 & 62 \\
\hline \multirow[t]{3}{*}{ S } & 5 & 114 & 109 & 83 & 122 & 116 & 147 \\
\hline & 10 & 46 & 39 & 43 & 49 & 42 & 73 \\
\hline & 15 & 18 & 13 & 24 & 19 & 14 & 39 \\
\hline \multicolumn{8}{|c|}{ Indianapolis, $M N$} \\
\hline \multirow[t]{3}{*}{$\mathrm{L}$} & 5 & 403 & 423 & 149 & 385 & 373 & 318 \\
\hline & 10 & 296 & 311 & 96 & 252 & 241 & 171 \\
\hline & 15 & 215 & 222 & 63 & 177 & 163 & 106 \\
\hline \multirow[t]{3}{*}{ M } & 5 & 288 & 287 & 125 & 229 & 216 & 215 \\
\hline & 10 & 176 & 168 & 72 & 133 & 116 & 112 \\
\hline & 15 & 113 & 100 & 44 & 87 & 71 & 67 \\
\hline \multirow[t]{3}{*}{ S } & 5 & 138 & 129 & 79 & 148 & 137 & 153 \\
\hline & 10 & 75 & 62 & 43 & 79 & 66 & 79 \\
\hline & 15 & 45 & 32 & 25 & 48 & 34 & 45 \\
\hline \multicolumn{8}{|c|}{ Charlotte, NC } \\
\hline \multirow[t]{3}{*}{$\mathrm{L}$} & 5 & 411 & 434 & 121 & 404 & 407 & 317 \\
\hline & 10 & 303 & 322 & 73 & 268 & 268 & 168 \\
\hline & 15 & 220 & 230 & 46 & 188 & 184 & 103 \\
\hline \multirow[t]{3}{*}{ M } & 5 & 292 & 301 & 108 & 242 & 244 & 216 \\
\hline & 10 & 184 & 189 & 60 & 148 & 145 & 113 \\
\hline & 15 & 120 & 115 & 36 & 98 & 91 & 66 \\
\hline \multirow[t]{3}{*}{ S } & 5 & 146 & 144 & 70 & 156 & 154 & 152 \\
\hline & 10 & 85 & 81 & 38 & 91 & 87 & 80 \\
\hline & 15 & 56 & 50 & 23 & 59 & 53 & 46 \\
\hline \multicolumn{8}{|c|}{ Orlando, FL } \\
\hline \multirow[t]{3}{*}{$\mathrm{L}$} & 5 & 301 & 382 & 96 & 376 & 399 & 299 \\
\hline & 10 & 214 & 279 & 52 & 243 & 271 & 138 \\
\hline & 15 & 151 & 207 & 26 & 170 & 200 & 69 \\
\hline \multirow[t]{3}{*}{ M } & 5 & 220 & 278 & 84 & 233 & 246 & 212 \\
\hline & 10 & 137 & 176 & 42 & 142 & 154 & 102 \\
\hline & 15 & 89 & 126 & 20 & 95 & 115 & 50 \\
\hline \multirow[t]{3}{*}{ S } & 5 & 114 & 149 & 56 & 152 & 159 & 150 \\
\hline & 10 & 68 & 91 & 28 & 90 & 97 & 76 \\
\hline & 15 & 45 & 67 & 14 & 60 & 71 & 38 \\
\hline
\end{tabular}

Note: U.S. study locations: Minneapolis, Minnesota (MN); Indianapolis, Indiana (IN); Charlotte, North Carolina (NC); and Orlando, Florida (FL).

south-positioned tree, especially a coniferous tree, should be avoided to minimize heating penalties. However, if this tree were necessary, proper pruning may help manage unwanted shade during the heating season. An increase in bole height (by pruning lower branches) would allow sunlight to better reach a dwelling, and thus increase passive solar heating. In southern latitudes (Orlando), with their longer cooling season, differences in shade between deciduous trees on the southern aspects (southeast, south, and southwest) would be subtle and the heating penalty less dire, and would there- fore be considered as a second option for a shade tree if the east or west aspects are not available.

\section{Plant the Right Tree in the Right Place}

The phrase "plant the right tree in the right place" has become a widespread philosophy for maximizing tree benefits and minimizing costs in urban areas. The results of these tree shade simulations have shown the importance of strategic tree selection and placement for optimizing shade, which has positive benefits for energy conservation and human comfort. 
Even though larger trees provide high levels of shade, they can also create possible hazards or conflicts when placed too close to a structure. The resulting problems, such as structural damage, could possibly negate the benefits of energy conservation (McPherson et al. 2005; McPherson et al. 2006; Peper et al. 2009; Peper et al. 2010). Therefore, the compromise between tree size and distance should be carefully considered when selecting and planting shade trees.

The use of a strategically placed single tree is amplified when one considers that shade trees can contribute to "spillover" shade benefits to neighboring structures, especially in dense urban developments (Nikoofard et al. 2011). These trees may also contribute to energy conservation by shading low albedo ground covers (e.g., streets and driveways) and by evapotranspiration cooling (Huang et al. 1987) and windbreak effects (Heisler 1986a). In addition, tree selection and placement must also be considered in the full context of the landscape situation and across the full range of potential benefits. For example, a greater environmental benefit may occur from placing a tree on a low-shade north aspect if its canopy projects over an impervious surface, thereby intercepting rainfall and delaying stormwater runoff. The key is to understand how tree form and tree placement interact with the built environment to derive a multitude of environmental benefits and then select the planting configuration that puts the tree to its highest use.

\section{CONCLUSION}

This study has demonstrated a simulation method to assess the impact of a single-tree planting configuration on shade provision for a prototypical residential structure in various geographic locations. To isolate some of the key variables, the simulations considered a contrived situation that simplified the geometry of the structure and placement of specific trees in selected geographic settings. As a result, it demonstrated that shade provision is influenced by not only tree form and placement, but also daily, seasonal, and latitudinal variability in sunlight exposure. These simulations support the general recommendation that large trees placed adjacent to buildings, on their east or west aspects, provide high levels of shade during the cooling season while minimizing unwanted shade during the heating season. However, the simulations indicate that in addition to the tree direction relative to the structure, tree distance should be considered in conjunction with tree size.
Quantity, quality, as well as timing of shade cast upon building surface areas impact the magnitude of shading benefits with regard to energy conservation and human health (Heisler 1986b). However, because this study only quantified shade provision, the authors cannot draw conclusions about how the quality of shade (e.g., shade of similar magnitude cast by an east versus a west aspect tree) impacts energy conservation. Through simulating shade effects specifically on building energy consumption, further studies could address this limitation. In addition, shade provision is not the only factor that influences building energy performance; for example, weather, building characteristics, and occupant behavior have notable impacts (Livingston and Cort 2011). Despite these limitations, this study has demonstrated the nuanced relationship between TPC variables, geographic latitudes, and shade provision across a broad spectrum of urban settings in the U.S. With these findings, researchers can move closer toward providing recommendations for optimal tree selection and placement based on geographic location in order to maximize shade benefits for both energy conservation and human health. Researchers' ability to make precise tree planting recommendations takes on even greater significance for urban neighborhoods where UHI effects are more acute, and potential tree planting space is more limited.

Acknowledgments. We would like to thank Dr. James R. Simpson for providing the Shadow Pattern Simulator (SPS) program and technical support, and Dr. Susan D. Day, Dr. James B. Campbell, and Tammy E. Parece at Virginia Tech for their valuable perspective for preparing the manuscript. We also acknowledge anonymous reviewers and the editors for their constructive comments.

\section{LITERATURE CITED}

Akbari, H. 2002. Shade trees reduce building energy use and $\mathrm{CO}_{2}$ emissions from power plants. Environmental Pollution 116: S119-S126.

Akbari, H., H. Pomerantz, and H. Taha. 2001. Cool surfaces and shade trees to reduce energy use and improve air quality in urban areas. Solar Energy 70(3):295-310.

Baechler, M.C., J. Williamson, T. Gilbride, P. Gole, M. Hefty, and P.M. Love. 2010. High-performance home technologies: Guide to determining climate regions by county. Accessed 12/04/2013. $<$ http://apps1.eere.energy.gov/buildings/publications/pdfs/ building_america/ba_climateguide_7_1.pdf $>$

Centers for Disease Control and Prevention. 2013. Climate change and extreme heat events. Accessed 12/04/2014. <www.cdc. gov/climateandhealth/pubs/ClimateChangeandExtremeHeat Events.pdf>

Donovan, G.H., and D.T. Butry. 2009. The value of shade: Estimating the effect of urban trees on summertime electricity use. Energy and Buildings 41:662-668. 
Harlan, S.L., A.J. Brazel, G.D. Jenerette, N.S. Jones, L. Larsen, L. Prashad, and W.L. Stefanov. 2007. In the shade of affluence: The inequitable distribution of the urban heat island. Research in Social Problems and Public Policy 15:173-202.

Harlan, S.L., A.J. Brazel, L. Prashad, W.L. Stefanov, and L. Larsen. 2006. Neighborhood microclimates and vulnerability to heat stress. Social Science \& Medicine 63:2847-2863.

Heisler, G.M. 1986a. Energy savings with trees. Journal of Arboriculture 12(5):113-125.

Heisler, G.M. 1986b. Effects of individual trees on the solar radiation climate of small buildings. Urban Ecology 9:337-359.

Hildebrandt, E.W., and M. Sarkovich. 1998. Assessing the costeffectiveness of SMUD's shade tree program. Atmospheric Environment 32(1):85-94.

Huang, Y.J., H. Akbari, H. Taha, and A.H. Rosenfeld. 1987. The potential of vegetation in reducing summer cooling loads in residential buildings. Journal of Climate and Applied Meteorology 26:1103-1116.

Knowlton, K., M. Rotkin-Ellman, L. Geballe, W. Max, and G.M. Solomon. 2011. Six climate change-related events in the United States accounted for about $\$ 14$ billion in lost lives and health costs. Health Affairs 11:1-10.

Ko, Y., and J.D. Radke. 2014. The effect of urban form and residential cooling energy use in Sacramento, California. Environment and Planning B: Planning and Design 41:573-593.

Kurita, A., and T. Sakurai. 1988. The power system failure on July 23, 1983 in Tokyo. pp. 2093-2097. In: Decision and Control, 1988: Proceedings of the 27th IEEE Conference, Austin, Texas, U.S.

Livingston, O.V., and K.A. Cort. 2011. Analyzing the impact of residential building attributes, demographic and behavioral factors on natural gas usage. Accessed 12/04/2014. <www.pnl.gov/main/ publications/external/technical_reports/PNNL-20235.pdf>

Luber, G., and M. McGeehin. 2008. Climate change and extreme heat events. American Journal of Preventive Medicine 35(5):429-435.

McPherson, E.G. 2010. Selecting reference cities for i-Tree Streets. Arboriculture \& Urban Forestry 36(5):230-240.

McPherson, E.G., J.R. Simpson, P.J. Peper, S.E. Maco, S.L. Gardner, S.K. Cozad, and Q. Xiao. 2005. Midwest community tree guide: benefits, costs, and strategic planting (General Technical Report NA-TP-05-05). Newtown Square, PA - U.S. Department of Agriculture, Forest Service, Northeastern Area State and Private Forestry. Accessed 10/14/2014. <www.fs.fed.us/psw/publications/documents/psw_gtr219/psw_gtr219.pdf>

McPherson, E.G., J.R. Simpson, P.J. Peper, S.L. Gardner, K.E. Vargas, S.E. Maco, and Q. Xiao. 2006. Piedmont community tree guide: Benefits, costs, and strategic planting (General Technical Report PSW-GTR-200). Davis, CA - U.S. Department of Agriculture, Forest Service, Pacific Southwest Research Station. Accessed 10/14/2014. <www.fs.fed.us/psw/publications/documents/ psw_gtr200/psw_gtr200guide.pdf>

McPherson, E.G., R. Brown, and R.A. Rowntree. 1985. Simulating tree shadow patterns for building energy analysis. pp. 378-382. In: A.T. Wilson and W. Glennie (Eds.). Solar 85: Proceedings of the National Passive Solar Conference. American Solar Energy Society, Boulder, Colorado, U.S.

National Oceanic and Atmospheric Administration. 2011. NOAA's 1981-2010 Climate Normals. Accessed 12/04/2014. <www. ncdc.noaa.gov/oa/climate/normals/usnormals.html>

Nikoofard, S., V.I. Ugursal, and I. Beausoleil-Morrison. 2011. Effect of external shading on household energy requirement for heating and cooling in Canada. Energy and Buildings 43:1627-1635.
Nowak, D.J., and E.J. Greenfield, 2012. Tree and impervious cover change in U.S. cities. Urban Forestry \& Urban Greening 11:21-30.

Patz, J.A., H.K. Gibbs, J.A. Foley, J.V. Rogers, and K.R. Smith. 2007. Climate change and global health: Quantifying a growing ethical crisis. EcoHealth 4: 397-405.

Peper, P.J., E.G. McPherson, J.R. Simpson, S.N. Albers, and Q. Xiao. 2009. Lower Midwest community tree guide: Benefits, costs, and strategic planting (General Technical Report PSW-GTR-219). Albany, CA - U.S. Department of Agriculture, Forest Service, Pacific Southwest Research Station. Accessed 10/14/2014. $<$ www.fs.fed.us/psw/publications/documents/psw_gtr219/ psw_gtr219.pdf>

Peper, P.J., E.G. McPherson, J.R. Simpson, S.N. Albers, and Q. Xiao. 2010. Central Florida community tree guide: Benefits, costs, and strategic planting (General Technical Report PSW-GTR-230). Albany, CA - U.S. Department of Agriculture, Forest Service, Pacific Southwest Research Station. Accessed 10/14/2014. <www.fs.fed.us/psw/publications/documents/psw_gtr230/ psw_gtr230.pdf>

Rudie Jr., R.J., and R.S. Dewers. 1984. Effects of tree shade on home cooling requirements. Journal of Arboriculture 10(12):320-322.

Sarkar, M. 2011. How American homes vary by the year they were built. Accessed 06/13/2014. <www.census.gov/housing/patterns/publications/HousingByYearBuilt.pdf>

Sawka, M., A.A. Millward, J. Mckay, and M. Sarkovich. 2013. Growing summer energy conservation through residential tree planting. Landscape and Urban Planning 113:1-9.

Simpson, J.R. 1998. Urban forest impacts on regional cooling and heating energy use: Sacramento County case study. Journal of Arboriculture 24(4):201-214.

Simpson, J.R. 2002. Improved estimates of tree-shade effects on residential energy use. Energy and Buildings 34(10):1067-1076.

Simpson, J.R., and E.G. McPherson. 1996. Potential of tree shade for reducing residential energy use in California. 1996. Journal of Arboriculture 22(1):10-18.

Simpson, J.R., and E.G. McPherson. 1998. Simulation of tree shade impacts on residential energy use for space conditioning in Sacramento. Atmospheric Environment 32(1):69-74.

Stone Jr., B. 2007. Urban and rural temperature trends in proximity to large U.S. cities: 1951-2000. International Journal of Climatology 27:1801-1807.

Troxel, B., M. Piana, M.S. Ashton, and C. Murphy-Dunning. 2013. Relationships between bole and crown size for young urban trees. Urban Forestry \& Urban Greening 12:144-153.

U.S. Administration. 2014. Fact sheet: Building community resilience by strengthening America's natural resources and supporting green infrastructure. Assessed 10/14/2014. <www. whitehouse.gov/administration/eop/ceq/Press_Releases/October_8_2014>

U.S. Census Bureau. 2012. 2012 Characteristics of new housing. Accessed 10/13/2013. <www.census.gov/construction/chars/pdf/ c25ann2012.pdf>

U.S. Energy Information Administration. 2014. How much electricity does an American home use? Assessed 12/04/2014. <www. eia.gov/tools/faqs/faq.cfm?id=97\&t=3>

U.S. Environmental Protection Agency. 2006. Excessive heat events guidebook. Accessed 10/03/2013. <www.epa.gov/heatisland/ about/pdf/EHEguide_final.pdf>

U.S. Global Change Research Program. 2009. Global climate change impacts in the United States. In: T.R. Karl, J.M. Melillo, and T.C. 
Peterson (Eds.). United States Global Change Research Program. Cambridge University Press, New York City, New York, U.S.

U.S. Government Accountability Office. 2012. Air emissions and electricity generation at U.S. power plants. Accessed 12/04/2014. $<$ http://gao.gov/assets/600/590188.pdf>

Walsh, B. 2013. 10 years after the great blackout, the grid is stronger - but vulnerable to extreme weather. Accessed 12/08/2014. $<$ http://science.time.com/2013/08/13/ten-years-after-thegreat-blackout-the-grid-is-stronger-but-vulnerable-to-extreme-weather>

Whitman, S., G. Good, E.R. Donoghue, N. Benbow, W. Shou, and S. Mou. 1997. Mortality in Chicago attributed to the July 1995 heat wave. American Journal of Public Health 87(9):1515-1518.

Wilson, W., T. Leipzig, and B. Griffiths-Sattenspiel. 2012. Burning our rivers: The water footprint of electricity. Accessed 12/08/2014. <www.rivernetwork.org/sites/default/files/Burning OurRivers_0.pdf>

Won Hoi Hwang (corresponding author)

Department of Forest Resources \& Environmental Conservation Virginia Tech

Blacksburg, Virginia 24061, U.S.

whwang@vt.edu

\section{P. Eric. Wiseman}

Department of Forest Resources \& Environmental Conservation Virginia Tech

Blacksburg, Virginia 24061, U.S.

pwiseman@vt.edu

Valerie A. Thomas

Department of Forest Resources \& Environmental Conservation Virginia Tech

Blacksburg, Virginia 24061, U.S.

thomasv@vt.edu

Résumé. L'urbanisation croissante, caractérisée par une augmentation des surfaces imperméables et une diminution de la canopée arborescente, contribue à la hausse des températures urbaines. Cette tendance a des implications sur la consommation d'énergie et sur la santé humaine que les arbres urbains peuvent aider à atténuer en ombrageant les surfaces extérieures des bâtiments. Cette étude examine comment la forme des arbres et leur localisation peuvent améliorer les pratiques actuelles de plantation des arbres en vue d'atténuer efficacement cette tendance. La qualité de l'ombre projetée ne découle pas uniquement des caractéristiques de l'arbre, mais aussi de la variabilité quotidienne, saisonnière et latitudinale de l'exposition solaire. Afin de comprendre comment ces variables influencent la qualité de l'ombre et évaluer les pratiques actuelles de plantation des arbres, une application informatique nommée Shadow Pattern Simulator a été utilisé pour quantifier l'ombre projetée par un seul arbre sur une structure résidentielle typique dans quatre villes américaines. Un total de 576 simulations de projection d'ombre a permis d'établir que des grands arbres situés à moins de cinq mètres selon une orientation est ou ouest de la structure procuraient la plus grande quantité d'ombre pendant la saison estivale. Les résultats des simulations confirment la justesse des pratiques de plantation des arbres selon une orientation est ou ouest, tout en évitant les plantations d'arbres du côté sud afin d'éviter que leur ombre ait un impact négatif sur les coûts de chauffage des bâtiments pour les latitudes plus nordiques. Cependant, la plantation d'arbres selon une orientation sud ne devrait pas être exclue puisqu'une courte saison froide diminue le préjudice causé par l'ombre des arbres à cette période de l'année tandis que leur ombre en saison estivale est grandement appréciée et réduit les besoins de climatisation.

Zusammenfassung. Eine expandierende Urbanisierung, charakterisiert durch zunehmend versiegelte Oberflächen und verminderte Baumkronenflächen trägt zum Anstieg urbaner Temperaturen bei. Dieser Trend hat Auswirkungen auf den Energieverbrauch und die menschliche Gesundheit, weil urbane Bäume diese Effekte durch Beschattung der Gebäudeoberflächen vermindern können. Diese Studie schaut darauf, wie Baumform und -platzierung die gegenwärtigen Richtlinien für Schattenbaumpflanzung verbessern können, um Schattenbäume gezielter verwenden zu können und den Trend abzuwenden. Die Lieferung von Schatten ist nicht nur eine Funktion von Baumeigenschaften sondern auch eine tägliche, saisonale und breitgrad-abhängige Variabilität in der Exposition zur Sonne. Um zu verstehen, wie diese Variablen den Schattenwurf beeinflussen und zur Bewertung existierender Baumpflanzrichtlinien, wurde ein Computerprogramm mit dem Namen „Shadow Pattern Simulator" (Schattenwurfsimulator) verwendet, wobei der Schattenwurf eines Baumes in einer prototypischen Siedlungsstruktur in vier US Städten quantifiziert wurde. Insgesamt 576 Schattensimulationen zeigten, dass große Bäume in ca. $5 \mathrm{~m}$ Abstand zur der Ost- oder Westseite der Struktur den größten Schatten während der Kühlperiode lieferten. Die Simulationsresultate bestätigen die existierenden Baumpflanzrichtlinien zur Pflanzung von Bäumen auf der Ost- oder Westseite und Vermeidung von Baumpflanzungen auf der Südseite zur Verminderung von Heizungsnachteilen von unerwünschtem Schatten in nördlichen Breiten. Dennoch sollte die Pflanzung auf der Südseite nicht unterbewertet werden, weil die kürzeren Heizperioden die ungünstigen Heizungsnachteile von unerwünschtem Schatten vermindern, während sie in der Kühlperiode angenehmen Schatten liefern.

Resumen. La ampliación de las urbanizaciones, caracterizada por el aumento de las superficies impermeables y disminución del dosel arbóreo, está contribuyendo al aumento de las temperaturas urbanas. Estas tendencias tienen implicaciones para el consumo de energía y la salud humana, que los árboles urbanos pueden ayudar a mitigar dando sombra sobre las superficies edificadas. Este estudio analiza de qué manera la forma del árbol y la ubicación pueden mejorar en las directrices de plantación de árboles de sombra actuales como un medio para utilizar con mayor eficacia los árboles de sombra para contrarrestar esa tendencia. La provisión de sombra no es sólo una función de las características de los árboles sino también de la variabilidad diaria, estacional y latitudinal en la exposición solar. Para entender de qué modo estas variables influyen en la provisión de sombra y para evaluar las pautas de plantación de árboles, se empleó un programa informático llamado Simulador de Patrón de Sombra para cuantificar la sombra proyectada por un solo árbol en una estructura residencial prototipo en cuatro ciudades de los Estados Unidos. Un total de 576 simulaciones de sombra mostró que los árboles grandes situados dentro de los cinco metros en la cara este u oeste con relación a la estructura dan la mayor cantidad de sombra durante la temporada fría. Los resultados de la simulación afirman las directrices actuales para la plantación de árboles de sombra en la cara este u oeste, y evitando la plantación de árboles en el sur minimiza el calentamiento de sombra no deseada en las latitudes septentrionales. Sin embargo, la plantación de árboles en la orientación sur no debe ser descontada porque la temporada de calor más corto reduce el calentamiento de sombra no deseada al tiempo que proporciona la tan necesaria sombra durante la temporada fría. 